This is the version of the article accepted for publication in Journal of Modern Craft published by Taylor \& Francis online 4 October 2016. Final version available at: http://dx.doi.org/10.1080/17496772.2016.1205279

Accepted version downloaded from SOAS Research Online: http://eprints.soas.ac.uk/22671/

\title{
Beyond yet Toward Representation: Diasporic Artists and Craft as Conceptualism in Contemporary Southeast Asia
}

Pamela N. Corey

Lecturer, Department of the History of Art \& Archaeology

SOAS, University of London

Brunei Gallery, B318

SOAS, University of London

Thornhaugh Street, Russell Square

London, WC1H 0XG

$\mathrm{BIO}$

Pamela N. Corey is Lecturer in Southeast Asian Art at SOAS, University of London. Her writings have appeared in Art Journal, Yishu: Journal of Contemporary Chinese Art, Udaya, Journal of Khmer Studies, and numerous exhibition catalogues and platforms for art criticism.

She is currently working on a book project that examines the development of contemporary art in relation to urban form in Vietnam and Cambodia.

\section{ABSTRACT}

This paper focuses on craft as a conceptual mediation within selected artworks by Dinh Q. Lê (b. 1968, Vietnam) and Sopheap Pich (b. 1971, Cambodia), two of the most internationally successful artists to represent Vietnam and Cambodia in the global art world. Through an analysis of earlier works that responded more immediately to time and place, I consider broader questions concerning diasporic subjectivity and the relationship between craft, conceptualism, and politico-historical representation in Southeast Asia. This reading finds a confluence between discourses of craft and conceptualism, particularly in the meeting point between abstraction and representation. The act of representation is interrogated in different ways, in which craft (as process) indexes a haptic gesture with ethnic identity, and craft (as form) operates in contemporary art's discursive regime as an exemplary return to material objecthood. In the examples discussed here, the artists have introduced a genre of conceptualism that is contingent upon a narrative, representational function, one still deemed vital in Vietnam and Cambodia, where a democratic historical project continues to be repressed by current political regimes. As such, I situate the artists' works beyond their predominant readings as signs of trauma, instead emphasizing the ways in which the artists have contributed to, and expanded, understandings of conceptual art in the context of Southeast Asia and elsewhere.

\section{KEYWORDS}

Vietnam; Cambodia; diaspora; contemporary art; conceptualism; craft 
On April 18, 2013, a symposium took place at the Queens Museum of Art as part of a public program accompanying the Guggenheim UBS MAP exhibition No Country:

Contemporary Art for South and Southeast Asia. ${ }^{1}$ Daravuth Ly, the Cambodian-born co-founder of the Phnom Penh-based Reyum Institute of Arts and Culture, ${ }^{2}$ gave a presentation in which he juxtaposed several examples of artworks by internationally prominent contemporary Cambodian artists with what might be considered counterparts in the vernacular realm or with precedent artworks that had not been recognized as falling within a similar purview of "contemporary art." Ly presented such comparisons in order to interrogate the perception and distinction of "Cambodian contemporary art" within a larger set of objects, displaying aesthetic contemporaneities and conceptual inclinations, in the context of Cambodian arts and culture. One such example included a 1998 sculpture by Prom Sam $\mathrm{An}^{3}$ and a 2003 rattan sculpture of lungs by Sopheap Pich (Figure 1), a work that launched Pich's sculptural praxis and led to current perceptions of Pich as the most internationally acclaimed contemporary artist from Cambodia today. ${ }^{4}$ To definitively answer the questions posed by Ly is no doubt a subjective enterprise, but it merits a closer analysis of how the constitution of discursive terms such as "vernacular," "conceptual," and "craft" are pinned, in large part, to visual markers. However, the analytical value of such terms are as contingent upon the objects' formal properties as they are upon their contexts of emergence, their specific historical and geographical circumstances. In this instance, the artist's point of view - or way of looking at certain materials and their perceived culturalspecificity - reveals the inflection that diasporic subjectivity may cast upon a relationship to historical representation.

In order to discern how craft, conceptualism, abstraction, and representation are simultaneously confounding yet structuring categories in the reception of contemporary art from 
Southeast Asia, this essay looks at two diasporic artists: Sopheap Pich (b. 1971, Battambang, Cambodia) and Dinh Q. Lê (b. 1968, Hà Tiên, Vietnam). ${ }^{5}$ Both artists left their birth countries under circumstances of extreme political unrest and violence, but returned as adults to resettle in Southeast Asia following politico-economic reforms and stabilizing living conditions enabled by processes of globalization. As such, they are also referred to as "returnee" artists, indicating a transnational subjectivity across Southeast Asia and the United States. Their ethnographic outlook and grasp of the aesthetic with an emphasis on "the local" is thus shaped by an overseas artistic formation but also by the immediacy of lived experience in the places from which they source creative inspiration, materials, and labor. It is a constellation of these factors that shapes the discursive regime, and no doubt, favorable international market reception, surrounding their work. ${ }^{6}$ An examination of select examples of their work in relation to these factors, and against the postcolonial and postwar setting in Vietnam and Cambodia, addresses Daravuth Ly's earlier query by considering how a mediation of "craft" can facilitate the international embrace of "Vietnamese Contemporary Art" and "Cambodian Contemporary Art." This analysis furthermore situates their work beyond what until now have been predominant readings of their works as signs of trauma and the refugee experience, instead emphasizing the ways in which the artists have contributed to, and expanded, understandings of conceptual art in the context of Southeast Asia and elsewhere.

Lê and Pich both belong to what is informally referred to as "the 1.5 generation," in that they left their respective birth countries as young children with refugee status, and both were raised and educated in the United States. Lê returned to Vietnam in 1997 and settled permanently in Ho Chi Minh City, and Pich returned to Cambodia and made his home in Phnom Penh in 2002. As such, the status of being a "returnee" complicates a broader understanding of the 
diasporic condition as one of exile and forced migration, without possibility of return. ${ }^{7}$ Yet as these two countries entered into globalization, with Vietnam's market-oriented reforms in 1986 and Cambodia's first post-Khmer Rouge democratic national election in 1993, conditions of mobility and residency have become much more flexible for those who had fled the countries in the late 1970s. For both artists, the decision to return was based on the desire to reconnect with the local culture, but also - in large part - to make deeper meaning of their art, which both have described as lacking somehow in orientation or profound meaning until they returned to their birth countries. Following their returns, Lê and Pich gradually became two of the most internationally successful artists to represent Vietnam and Cambodia in the global art world. Lê's craft-based engagements with media imagery related to the Vietnam War and Pich's exoskeletal woven rattan sculptures forged their paths to global success, and they would be the first Vietnamese and Cambodian-born artists to have solo exhibitions at venues such as The MoMA, the Metropolitan Museum of Art, and dOCUMENTA. "Craft" underpins the appeal of their work, even if the term itself holds a range of sensibilities. Craft can be understood as a cultivated labor signifying tradition, locality, cultivation of the self, and, in these artists' works, as a material mediation of abstraction and representation. Therefore, of acute importance here are the ways in which the artists deploy craft as a vehicle to create conceptually-driven formal iterations, drawing both on semiotic play, such as language, as well as material subversions, e.g. the recombination of photographic fragments to produce a pictorial dialectic. My choice of the term "conceptual" describes earlier works that emerged from and were created for a particular local context, that of urban publics in contemporary Vietnam and Cambodia. Yet, I would suggest that this characterization persists today, even as their artworks have circulated predominantly outside of those countries. These examples further illustrate the multiple, and what may appear to be 
overlapping, definitions of craft and conceptual art, particularly in postcolonial and postwar Southeast Asia.

Returning to Daravuth Ly's question comparing the works by Prom Sam An and Sopheap Pich, a confluence of elements enabled the international success of the latter work. These include the legibility of semiotic narrative, the visuality of modernist abstraction, and the indexing of a seemingly culturally specific hand-made artisanal tradition. The disentanglement of these components foregrounds the discursive value of recurring terms such as "craft," "conceptualism," and "diaspora," with consideration of their broadly defined usage and historicization. Individual strands of definitional specificity can be teased out from their very entanglement in analyses of these artworks, going beyond an exercise in the clarification of terminology to a deeper understanding of how art from Southeast Asia is represented within the increasingly institutionalized category of "global contemporary art." In terms of artists' visual references and sources of inspiration, it is important to note that, in many instances, those objects and practices informing the production of "contemporary art" are those that often fall outside of that context of discourse and circulation, for example, the woven grass objects or rattan fishing traps that are examples of functional and aesthetic implements found in rural Southeast Asia (Figure 2). ${ }^{8}$ It can be argued that there are few Southeast Asian artists whose works have been described as conceptual who do not in some way engage with legible, however diversely expressed, craft categories or processes. This craft element holds an indexical quality that presents - or performs - the "local," thus amplifying the success of such work in international exhibitions, markets, and museums.

As Julia Bryan-Wilson noted in a series of polemical propositions on craft and contemporary art, "Craft saturates the landscape of recent current art; it has threaded itself into 
and onto any map of the international art world. ${ }^{\prime 9}$ Outside of Europe and the United States, craft - referring to a precise haptic manipulation of materials toward ultimate object fabrication - has been a key vehicle for the designation of contemporary art. In Southeast Asia, during the 1970s and 1980s, the use of local and found materials hailed for some artists the turn from the modern to the contemporary. ${ }^{10}$ In the emphasis on conceptualism as the defining basis of contemporary art, such practices found commonalities but also divergences from Euro-American discursive framings. While these discourses in themselves lacked uniform consensus, overarching characterizations of conceptualism have tended toward process, seriality, fragmentation, and arguably, anti-formalism and anti-materialism, attributes of a 1960s New York-based community of artists strongly influenced by Fluxus. ${ }^{11}$

In a similar fashion, in Southeast Asia, works described as conceptual also drew on alternative new expressive forms introduced during the 1970s, namely performance, installation, and the use of found objects to carry out social and political critique. ${ }^{12}$ Apinan Poshyananda has described the hesitation of many Southeast Asian artists to explore these media, given institutional fears that it would provide students with further means to challenge authority. ${ }^{13}$ But with intensifying processes of globalization and neoliberalization throughout the region in the 1990s and the beginning of the new millennium, craft-based experiments in contemporary art served as a means of exploring dialogical engagements with tradition, identity, formal experimentation, and social and political critique. Redza Piyadasa, Roberto Chabet, and Cheo Chai Hiang, among others acclaimed as pioneering artists driving conceptualism in Southeast Asia in the 1970s, were noted for the complexity of their practices that could, on the one hand, be rendered legible within the frameworks of art as language, the ready-made, and institutional 
critique, but on the other hand, served as profound interrogations of more complex and localized discourses on national identity and the vexed role of modernist or realist painting. ${ }^{14}$

For other artists, redeploying institutionalized modes of craft production or iconographic art objects facilitated more accessible and provocative means of subversive expression, for example, Indonesian artist Heri Dono's repertoire of forms drawn from Indonesian wayang kulit (shadow puppetry). For others, such as the late Vietnamese artist Vũ Dân Tân, craft methods both improvisational and cultivated - served as a way to shift paradigms of artistic representation away from painting on canvas, with its colonial residues as the predominant focus in institutional pedagogy and tourist markets, and to signal the vitality of the vernacular, the ephemeral, and the locally-sourced. ${ }^{15}$ In Vietnam, craft traditions have held particular appeal for diasporic artists who have returned to study traditional art forms and to further develop their own practices, as in the case in Phi Phi Oanh's commitment to stretching the perceptual possibilities of lacquer beyond its boundedness as a surface treatment (Figure 3). ${ }^{16}$ In the case of the former colonies and colonial protectorates of the French Indochinese Union (Indochine), which includes Vietnam, Laos, and Cambodia, there is what may be perceived as a postcolonial imperative at work, given the prestige colonial pedagogical directives assigned to certain categories of handmade work classified as authentic expressions of native culture. ${ }^{17}$

In the 1970s and 1980s, numerous countries in Southeast Asia saw the onset of these experimental artworks heralding what historiographies would periodize as "contemporary art." Such developments came later in Vietnam and Cambodia due to the upheaval of the Vietnam War, and in Cambodia, the genocidal regime of Pol Pot (1975-1979). At the time of Lê's return to Ho Chi Minh City in 1997 and Pich's return to Phnom Penh in 2002, there were particular gaps in artistic and historical discourse that the two felt keenly, given their backgrounds as 
refugees and artists trained in U.S. institutions. In Vietnam, Lê and other returnee artists faced an absence of knowledge and discussion of the Vietnam War, and in particular, the history of the mass refugee movement. For some artists, this was refreshing, given the rise of identity politics as a trend in contemporary art in the U.S. These artists felt constricted by ethno-national categories and the expectation that their work would contribute to a larger project of American reconciliation with its involvement in the war. In Vietnam there has also been a gap in the historiography of Vietnamese artistic modernism, accounted for as a northern trajectory from the Ecole des beaux-arts de l'Indochine in Hanoi. ${ }^{18}$ The regional exclusion of artists from southern Vietnam reveals the state's privileging of a politicized national art history omitting the participation of southern postcolonial and émigré artists. At the same time in Cambodia, much of artistic production evoked - in Ingrid Muan's description - a gap between reality and permissible representation, a surface treatment oriented away from a capture of reality and the trauma of recent history. ${ }^{19}$ Muan keenly sensed this disjuncture at the turn of the millennium in Phnom Penh, prior to the surging international interest in Cambodian art contending with trauma and memory, a thematic focus that would stake a presence in NGO-driven art markets, and later, global exhibitionary circuits.

Both Pich and Lê have made significant contributions to the development of community discourses of contemporary art in their respective cities of settlement, and indirectly, toward local understandings of craft and conceptual art. Pich's woven rattan sculptures have received multiple acclaims both in Cambodia and internationally, most notably tied to the appeal of the vernacular, the visibility of labor, and a modernist aesthetic synthesizing abstraction and the figurative. Born in the province of Battambang, Pich and his family left as refugees at the wane of the Pol Pot regime. Eventually settling in the United States, Pich studied drawing in both his 
undergraduate and graduate studies. After unsuccessfully persevering with painting after his resettlement in Phnom Penh, he experimented with a sculpture of lungs for a 2004 exhibition at the French Cultural Center. The lungs, made from a rattan armature that he then intended to cover with cigarette packet wrappings, commented on prevalent health issues affecting Cambodians. During a studio visit by Guy Issanjou, the director of the French Cultural Center, Issanjou suggested that Pich leave the armature uncovered, that it was "the first modern sculpture he had ever seen in Cambodia, ${ }^{20}$ a statement that compelled Pich to pursue a sculptural practice. He taught himself to master the unpliable and unforgiving material of rattan, and as his career blossomed, he trained a group of assistants to fabricate the objects. Pich has since developed in a sophisticated technology of craft to realize various sculptural series ranging from formal representation to abstraction. Buddhas, body organs, urban architecture, utilitarian implements, and morning glory traverse the spectrum from figurative to non-figurative, all carefully realized in sinuous structures shaped from interwoven lines of bamboo, rattan, and wire (Figure 4). Recent works include a series of grids referencing high modernism and Arte Povera and a commissioned 26 foot-high site-specific installation at the Indianapolis Museum of Art.

It is important to note that audience was an important factor in Pich's turn to sculpture from painting, the focus of his MFA studies at the School of the Art Institute of Chicago. ${ }^{21}$ Sculpture held more legibility and prestige for local publics in Cambodia, given the weight of Angkor's rich architectural and sculptural art history. For a 2010 solo exhibition at the French Cultural Center in Phnom Penh, Pich created two woven rattan sculptures comprised of letters that, however deceptively facetious they may appear, contain an interpellatory function. One group of letters spells out "art" (silpah, but commonly transliterated as "selapak") in the Khmer script (Figure 5), the other "sculpture" (camlak'). Specifically addressing a Khmer-literate 
audience, the works act as utterances, performatively declaring the nature of their objecthood. Drawing upon imagistic and linguistic properties, the sculptures effect an alternative paradigmatic framing of contemporary art beyond the more ubiquitous representational painting styles featured in local art galleries at the time. Pich described his desire to address a Cambodian audience:

I chose these two Khmer words because I am beginning to make work that is directly aimed at the Cambodian public. I wanted them to think about questions such as "What is sculpture? What is art?" It is a way to interact with the general public here. [...] And they did seem to enjoy seeing the alphabet. What I have talked about with the Cambodian media and public was more about the love of one's work. The attention to details as a way of meditation, or that paradise is at our fingertips when we do something with care. Things like that, which many of them were surprised and happy to hear. I told them that the meaning of art is not always what the picture is trying to "explain" to us, but [it is] in the way that the object is made. ${ }^{22}$

Furthermore, their material reference to rural craft, namely woven rattan baskets, fishing traps and implements, presented a form of conceptual intervention through the display of the "Art" (silpah) sculpture in subsequent group exhibition at the National Museum of Cambodia, site of the former School of Cambodian Arts, in Phnom Penh. ${ }^{23}$ At this site, such a work also speaks to the history of Cambodian art education established by the French in the early twentieth century, which operated within a broader colonial rhetoric surrounding what they deemed to be 
the ever-declining state of culture since the epoch of Angkor, the name used to refer to the Khmer empire and its artistic and architectural program from roughly the $9^{\text {th }}$ to the $13^{\text {th }}$ centuries. As such, colonial administrators focused on recuperating the imperiled "Cambodian arts,",24 defined as traditional craft practices associated with ornament, thereby excluding anything perceived as bearing Western or modern influence. This was an embrace of the artisanal associated with court and commodity, including masks, silverwork, lacquerware - objects traditionally produced for a royal or elite clientele, and later, through the School of Cambodian Arts, disseminated through channels for international collection and consumption. ${ }^{25}$ As Boreth Ly has argued, the "Art" and "Sculpture" works subvert nationalist and colonial artistic hierarchies predicated on a strict and serialized vocabulary of materials and methods, thereby "[decolonizing] art in a colonial space.,"26

Pich's fabrications made of perceivably coarser materials speak to the everyday implements of the rural population, yet have spurred iterations in the realms of contemporary art and design. ${ }^{27}$ As such, the numerous attributions of the modernist quality of Pich's sculptures brings those objects simultaneously within the fold of discourses pertaining to craft and to modernism, in the emphasis on process, material, and scale. Issanjou's declaration that Pich's sculpture-in-progress was the "first modern sculpture" in Cambodia reveals an attraction to a mode of abstraction found elsewhere in postcolonial Southeast Asia but never developed as a distinctive art historical period in Cambodia. ${ }^{28}$ Alongside his inspiration from early $20^{\text {th }}$-century European modernists such as Brancusi and Giacometti, and the collection of Angkorian sculpture displayed at the National Museum in Phnom Penh, a decisive factor in his work revolves around the exposure of material imperfections and evidence of process. 
One answer to Daravuth Ly's inquiry - what effected the success of Pich's lungs as opposed to Prom Sam An's similar experiment with abstract sculpture and found materials - may lie within the Pich's method of manipulating a raw material for artistic purposes. Here, the evident manual alteration of rattan into referential forms hold more evocative allure for international audiences than a minimalist recomposition or re-assemblage of local found objects. For an art-going Cambodian public, including students and a younger generation of artists, the ambitious experimentation with a familiar craft technique and presentation of a scalar relationship in which sculptures shape the spatial environment informed additional ways of thinking about integrating craft and contemporary art. Regionally, formal comparisons can be made between Pich's sculptures and those by Indonesian artist Nindityo Adipurnomo, for example, the latter's 2003 sculptural installation Producing and Reproducing Identity, yet there is a significant difference in Pich's attention to negative space and the perceived porosity of the form as vessel, to the shadow effects cast by the gridded lines rendering the surrounding space experiential. Such concerns with treatment of surface and impression of volume, both of the freestanding form and the two-dimensional ground, reveal a committed praxis also shaped by his background in painting.

For Dinh Q. Lê and other returnee artists in Vietnam, like Tiffany Chung and Tuan Andrew Nguyen, craft industries have provided valuable sources of creative inspiration as well as means of fabrication for works serving as critical interventions into fraught transnational histories. ${ }^{29}$ Lê is perhaps most recognized for his body of work attending to the history of the Vietnam War and refugee experiences, realized in media including installation, video, and sculpture, often based on historical research, ethnographic observation, and the collection of found materials. It is important to note however that craft, labor industries, and photography 
have been consistent artistic preoccupations. Lê's engagement with craft can be perceived as two-fold: at the level of the informal sector and what Iftikhar Dadi has termed urban-craft, with his Damaged Gene project, and the essential role of the haptic encounter and the hand-made in his photo-weavings and embroidered pieces.

Lê's self-professed obsession with the Vietnam War and its refugee plight has notably driven his practice since he returned to settle in Vietnam in $1996 .{ }^{30}$ His first work about the Vietnam War was made in 1988, in the United States, in response to a course on the Vietnam War that he took during his undergraduate studies at the University of California, Santa Barbara. Reacting to the focus on the American experience of the war, Lê created posters with photographic images and facts about the number of Vietnamese casualties and posted them around campus. This desire to publicly enact such commentary was followed through in one of his earliest works in Ho Chi Minh City, deemed by many to be one of, if not the, most significant public participatory projects to have taken place in the city. The Damaged Gene project (August 1998) concerned the controversial subject of the use of the chemical defoliant Agent Orange during the Vietnam War, its lasting effects on the living population, namely as birth defects, and the United States' refusal to acknowledge responsibility at the time. Lack of public discourse could be attributed to superstition that open speech could lead to actualization of one's fears, such as giving birth to children with deformations, evidenced in cases of Siamese twins. Silence at the state level was tied to the government's prioritization of agricultural exports during a time when Vietnam was attaining a rising position in international trade following the 1986 marketoriented reforms known as “Renovation” (Đổi Mới).

For one month Lê rented a kiosk at a busy marketplace in Ho Chi Minh City, and had baby clothes and toys fabricated to be sold (Figure 6). These included knitted sweaters and 
pacifiers for and plastic toy figurines of conjoined twin babies (Figure 7). In addition, garments made to appear as cheap brand name knock-offs were embroidered with the names of chemical companies that had produced Agent Orange. At a cursory glance the dolls and clothing assimilated with other mass-produced wares made locally or in China, therefore initially disguising their peculiarities. However, Lê recalled the risk involved with the public display and its interactive dimension: "Culturally I was bringing a taboo subject and putting it right in the middle of the market for one month. It was the scariest opening I have ever held." ${ }^{31}$ Lê was right to consider the inherent dangers of the project, yet there were numerous elements that mitigated the chance that such a presentation would be construed by cultural authorities as a defiant political action. Lê was at an early stage of his career, and was not yet subject to the surveillance that he experiences today as a prominent figure in the artistic and cultural community of Ho Chi Minh City. Furthermore, while at one level his garments and toys were immersed in a panoply of commercial goods visually indiscernible to the casual glance of passersby, at another level, the toys in particular could be viewed alternatively through the lens of an artistic heritage in which bodhisattvas such as Quan Âm (Avalokitesvara), often depicted with multiple arms, would be part of a familiar cultural lexicon, further obscuring the objects' abnormality until closer scrutiny.

The works' guise as what Iftikhar Dadi has termed "urban craft" thus served to mask the public intervention. In an essay by Dadi on the inevitable meeting point between modernity, mass production, and craft, he describes this genre of "urban craft" as one that persists as an ever-multiplying material trace of tradition enabled by entwined structures of popular culture, capitalism, and the informal sector. Dadi notes that objects such as the ones in Damaged Gene 
do not circulate as tourist souvenirs or objects that consciously embody an invented tradition, yet a forceful argument can be made for continuity from the reappearance of morphological correspondences with traditional motifs... And yet these comparisons remain important in evoking prior meanings, which cannot be fully excised by appeals to a homogenising modernity but persists and returns constantly, here seen in the guise of urban-craft. ${ }^{32}$

Together with the 1999-2000 Lotus Land series (Figure 8), a group of related toy figurines further evoking the multi-armed deities from Hindu-Buddhist artistic traditions, these works illustrate how together with Lê's inclination to provoke discussion about the current effects of Agent Orange, Vietnam's growing status as a key supply center for children's garments and toys facilitated Lê's use of popular craft as a conceptual intervention into the everyday urban landscape. Whereas Pich may be seen as mediating rural craft into contemporary art, I suggest that with the Damaged Gene project and Lotus Land series, Lê effected a sequence of reversals: first circulating contemporary art as urban craft - seemingly mass-produced popular objects - in a public marketplace, and then re-scaling their forms and developing serial versions for global contemporary art circuits.

In a similar fashion to Pich's sculptural oeuvre, historical representation, craft, and modernism are evoked in Lê's works centered on the material and pictorial properties of photography, which also find connections to the conceptual and formal concerns that underpinned Damaged Gene. Given the ways in which photography and the moving image have been foundational materials driving the metaphor of "Vietnam" as geopolitical quagmire, for Lê, crafted manipulations of what is largely perceived as a mechanized medium have served as a key 
method of contesting popular representations of Vietnam in historical accounts and popular media from the United States. In an ongoing series described as photoweavings or phototapestries, Lê uses a method of grass mat weaving learned from his aunt in his childhood, and honed during his MFA studies at the School of Visual Arts in New York. From the first major iteration in 1998 until now, Lê has developed increasingly complex means of interweaving strips of photographs referencing iconic images pertaining to Cambodian and Vietnamese history extracted from documentary and journalistic photography and Hollywood films. The arresting tension produced by the enmeshed imagery is the result of a visual slippage between what seem to be polarized metonymic associations of place in series such as Cambodia: Splendor and Darkness (1994-9) (Figure 9), and Vietnam to Hollywood (2003-6) (Figure 10). The use of the photographic prints gestures towards their emblematic status as the fundamental instrument of the project of modernity and its desire to document and classify, while the act of weaving revisits traditions of haptic labor retrieved from the artist's childhood memories. However, Lê was also inspired by modernist collage when developing the weaving methodology, and saw it as a collage-based pictorial endeavor enacted through weaving. ${ }^{33}$ An earlier work from Cambodia: Splendor and Darkness demonstrates the level of skill with which Lê refined this technique, manipulating specific areas in relief and others into recession (Figure 9). To the cursory eye this produces a near digitally-rendered effect of fluid exchange between the imagery, similar to the perceptual-cognitive delay also triggered by the Damaged Gene fabrications in their setting at an urban marketplace. At the same time, the photoweavings index legible - however non-specific patterns from Southeast Asian textile traditions, enabling the artworks to travel across exhibitionary categories ranging from contemporary art to photography to textiles. 
These examples scratch the surface of how craft is used to embody narratives beyond what Maria Elena Buszak has described as a primary engagement with the "socio-cultural meaning of the material itself, ${ }^{, 34}$ while participating in multiple regimes of representation, from discursive frames of conceptualism, contemporary art, craft, and tradition. The interest in materials and imagery tied to historical, social, and political contexts in the works of numerous diasporic returnee artists in the region reflects both ethnographic and historical investigation, and a desire to interpellate both particular and multiple publics. While Lê's Damaged Gene project was locally-specific in terms of serving as a public urban intervention, his photo-weavings address a Euro-American audience for whom the Vietnam War is argued to have hailed the condition of postmodernity. ${ }^{35}$ Pich's intention was to produce art relevant for a local Cambodian community for whom such forms would resonate with the sculptural legacy of Khmer art history. As such, the works of Pich and Lê are useful for thinking about the ways in which the act of representation is invoked in different ways. As contemporary art, craft often indexes manual process with cultural-specificity, while at the same time, as a formal proposition, operates as an exemplary return to material objecthood. However, the nostalgic value potentially pinned to the visuality of craft holds discrepant functions and meanings depending on place and community. In the examples discussed here, the artists have introduced a genre of conceptualism that is contingent upon a narrative, representational function, one still deemed vital in Vietnam and Cambodia, where a democratic historical project continues to be repressed by current political regimes. As such, Lê and Pich negotiate the conceptual value of their praxis through localized meanings and narrative elements that can be construed semiotically, thereby emphasizing the immanence of representation in craft as form and process, and the role of conceptualism in bridging craft and contemporary art. 


\section{NOTES}

I would like to thank the editors and the article reviewer for their constructive suggestions during the revision process. I would also like to thank Iftikhar Dadi and Kevin Chua for their comments on an earlier version of the essay.

1. No Country: Contemporary Art for South and Southeast Asia was the first exhibition to take place as part of the Guggenheim UBS MAP Global Art Initiative, a series of exhibition, acquisition, and education programs supported by the Switzerland-based global financial services company UBS, formerly an abbreviation for the Union Bank of Switzerland. The initiative was organized into three regional components consisting of South and Southeast Asia, Latin America, and the Middle East and North Africa. The project website can be found at http://www.guggenheim.org/guggenheimfoundation/collaborations/map.

2. Reyum was a non-profit space established by American art historian Ingrid Muan (19642005) and Cambodian-born Ly Daravuth, who functioned in multiple capacities as curators, teachers, artists, ethnographers, and historians. Reyum ceased active programming in 2010. A more detailed discussion of its objectives and impact can be found in Ashley Thompson, "Forgetting to Remember, Again: On Curatorial Practice and 'Cambodian Art' in the Wake of Genocide," Diacritics 41, no. 2 (2013), p. 82-109.

3. Prom Sam An's sculpture from 1998, titled Air Bridge, comprised a miniature wooden boat form supported by an arching steel frame on top of an overturned clay pot. An image can be found at Reyum Institute of Arts and Culture: Past Exhibitions: "Communication," http://www.reyum.org/exhibitions/exhibit1/exhibit_photo_gallery.html\#A 
4. Pich has had solo exhibitions at the Indianapolis Museum of Art (2014), the Metropolitan Museum of Art in New York (2013), the Sherman Contemporary Art Foundation in Sydney, Australia (2013), and the Henry Art Gallery in Seattle, Washington (2011).

5. While this article follows the current international usage of their names as established by the artists, their given names are Lê Quang Đỉnh and Pich Sopheap following the Vietnamese and Khmer language conventions of placing the family name first.

6. Việt Lê elaborates upon tensions surrounding the local and global reception of returnee artists in his essay "Many Returns: Contemporary Vietnamese Diasporic ArtistsOrganizers in Ho Chi Minh City," in Modern and Contemporary Southeast Asian Art: An Anthology, eds. N. Taylor and B. Ly (Ithaca, NY: Cornell University Southeast Asia Program Publications, 2012), p. 85-116.

7. For an overview of the multiple uses and political ambivalence of the term, see James Clifford, “Diasporas," Cultural Anthropology 9, no. 3 (August 1994), p. 302-38.

8. See Pamela N. Corey and Ashley Thompson, "Note from the Editors," and Chea Narin, "Jrae Leaf Screens," in "On Modern and Contemporary Art and Aesthetics," Special Issue of Udaya, Journal of Khmer Studies 12 (2014), p. 4; 327-30.

9. Julia Bryan-Wilson, "Eleven Propositions in Response to the Question: "What Is Contemporary about Craft?” The Journal of Modern Craft 6, no. 1 (March 2013), p. 8.

10. See Jim Supangkat, "Contemporary Art of the South," in Contemporary Art of the NonAligned Countries: Unity in Diversity in International Art (Jakarta: Balai Pustaka: Project for Development of Cultural Media, Directorate General for Culture, Dept. of Education and Culture, 1997), p. 20-32, and Apinan Poshyananda, “'Con Art' Seen from the Edge: The Meaning of Conceptual Art in South and Southeast Asia," in Global Conceptualism: 
Points of Origin, 1950s-1980s, eds. Luis Camnitzer, Jane Farver, Rachel Weiss, and László Beke (New York: Queens Museum of Art, 1999), p. 143-48.

11. Lucy Lippard speaks to this place-based and historicized conception of Conceptualism in her essay "Escape Attempts," in Six Years: the Dematerialization of the Art Object From 1966 to 1972: A Cross-Reference Book of Information on Some Esthetic Boundaries (New York: Praeger, 1973), p. vii-xxii.

12. Poshyananda, ““Con Art',” p. 146.

13. Ibid., p. 143.

14. See Isabel Ching, "Tracing (Un)certain Legacies: Conceptualism in Singapore and the Philippines," Asia Art Archive Diaaalogue July 2011, http://www.aaa.org.hk/Diaaalogue/Details/1045; Patrick Flores, "Social Realism: The Turns of a Term in the Philippines," Afterall 34 (Autumn/Winter 2013), http://www.afterall.org/journal/issue.34/social-realism-the-turns-of-a-term-in-thephilippines; Ahmad Mashadi, "Framing the 1970s," Third Text 25, no. 4 (2011), p. 40917; and Simon Soon, “An Empty Canvas on which Many Shadows Have Already Fallen," in Narratives in Malaysian Art Volume 2: Reactions - New Critical Strategies, eds. Nur Hanim Bt Mohamed Khairuddin, Beverly Yong, and T.K. Sabapathy (Kulala Lumpur: Rogue Art, 2013), p. 55-69.

15. Supangkat, "Contemporary Art of the South," p. 24.

16. In 1994 the currently Hanoi-based Vietnamese-American artist Phi Phi Oanh received a Fulbright scholarship to study traditional lacquer painting in Hanoi, and has since established an acclaimed body of work predicated on experimentation with the medium. See Phi Phi Oanh, "A Contemporary Approach to Vietnamese Lacquer Painting," in Arts 
du Vietnam: Nouvelles Approches, eds. Caroline Herbelin et al. (Rennes, France: Presses Universitaires de Rennes, 2015), p. 167-72.

17. Artisanal practices such as silverwork, mask-making, lacquerware, and ceramics were institutionalized as "art" through colonial pedagogy and museology, although the alignment of definitions of art and craft with educational formation varied across the regional schools throughout French Indochina. Out of the colonial art schools established in Hanoi, Gia Định, Biên Hòa, Thủ Dầu Một, and Phnom Penh, the one in Hanoi was the only one based on the École des beaux-arts model, with the pedagogical embrace of "modern" artistic techniques. For further information, see Nora Taylor, "Orientalism/Occidentalism: The Founding of the Ecole des Beaux-Arts d'Indochine and the Politics of Painting in Colonial Việt Nam, 1925-1945," Crossroads: An Interdisciplinary Journal of Southeast Asian Studies 11, no. 2 (1997), p. 1-33.

18. The episode of postcolonial modernism in the south has only recently begun to be addressed by state institutions and art historians within Vietnam. After Renovation, southern artists experimented with new forms such as performance and installation later than their counterparts in the north, who were seen as the experimental avant-garde of Vietnamese art. For more information about specific developments in contemporary art in southern Vietnam, see Boitran Huynh-Beattie, "Vietnamese Aesthetics from 1925 Onwards" (PhD Diss., University of Sydney, 2005), and Pamela N. Corey, "Three Propositions for a Regional Profile: The History of Contemporary Art in Ho Chi Minh City," Arts du Vietnam: Nouvelles Approches, eds. Caroline Herbelin et al. (Rennes, France: Editions Presses Universitaires de Rennes, 2015), p. 135-44. 
19. Ingrid Muan, "Haunted Scenes: Painting and History in Phnom Penh," Udaya, Journal of Khmer Studies 6 (2005), p. 15.

20. Asia Art Archive, "Presentation by Sopheap Pich," October 30, 2011, http://www.aaaa.org/programs/presentation-by-sopheap-pich/, and conversations with the author 20092013.

21. I discuss this turn in more depth in "'The 'First' Cambodian Contemporary Artist'," Udaya, Journal of Khmer Studies 12 (2014), p. 72-75.

22. Artist's quote from Boreth Ly, "Of Transnational Subjects and Translation," Modern and Contemporary Southeast Asian Art: An Anthology, eds. Nora Taylor and Boreth Ly (Ithaca, NY: Cornell Southeast Asia Program Publications, 2012), p. 128.

23. The School of Cambodian Arts was established in 1917 by French painter and colonial administrator George Groslier, whose vision of preserving particular forms of Cambodian art drove the pedagogical direction of the school until the end of the Protectorate and the declaration of national independence in 1953. For further information on the school's founding and imbrication in market networks, see Gabrielle Abbe, "Le Développement des Arts au Cambodge à l'Époque Coloniale: George Groslier et l'École des Arts Cambodgiens (1917-1945)," Udaya, Journal of Khmer Studies 12 (2014), p. 7-39, and Ingrid Muan, "Citing Angkor: the 'Cambodian arts' in the age of restoration, 1918-2000" (PhD Diss., Columbia University, 2001).

24. See Muan, "Citing Angkor," for the political and ideological uses of the term "Cambodian arts" in the colonial context.

25. See Abbe, "Le Développement des Arts au Cambodge à l’Époque Coloniale." 26. Ly, “Of Transnational Subjects and Translation,” p. 128. 
27. It is possible to claim that Pich's work should be recognized as a predecessor to other Cambodian artists' large-scale sculptures woven from rattan and other materials that can be seen to have proliferated from 2009-2012. Formal similarities can be found in the 2009 Exhale series by Meas Sokhorn (b. 1977) and various sculptural works by Battambang-based Mao So Viet (b. 1981). Rather than seeing these artists as copying Pich, it is more fruitful to understand these artists as working in an experimental vein with similarly locally-sourced materials, and attempting to adhere to a method of recycling. Sokhorn has acknowledged his friendship with Pich, and the fact that he often sought advice from Pich; it is unsurprising that some influence would be derived from the exchange. The stigmatized notion of copying is also a more complex concept for many emergent artists, particularly as it is an institutionally-driven pedagogical method. While the method of copying is critiqued for its predominance in the curriculum at the Royal University of Fine Arts, driven by a focus on style and mastery of technique that may have origins in George Groslier' pedagogical mission for the School of Arts in 1920, it is nonetheless a rigorous exercise implemented in postsecondary art schools almost everywhere during the beginning levels of instruction. Therefore, examples of this form of experimentation with similar materials often serves as a stage in artistic formation.

28. It is difficult to locate mid-twentieth century Cambodian painters within this paradigm of artistic modernism. There were modern painters who pursued new practices of painting en plein air under the postcolonial pedagogy shaped by the Japanese artist Suzuki, but extant artworks and records from the 1950s and 1960s reveal little in common with experimental practices connected to cubism, abstraction, surrealism, among others, that occupied artists in places like South Vietnam, India, the Philippines, Cuba, and Senegal. 
29. Of note here and in the previous discussion of Pich's work are artists' access to fabrication resources, chiefly in the form of workshop assistants, allowing for the ambitious realization of deftly crafted and sizeable artworks, in some instances necessitating warehouse-sized studio spaces. The cost of land and labor in Vietnam and Cambodia has been a crucial factor in the production of such works, as it has been for numerous artists once their commercial success has ensured growing and stabilizing income.

30. Conversations with the author, 2010-2012.

31. Chanika Svetvilas, "The Art of War," Dialogue, Spring-Summer 1999, 27-28. Cited in Moira Roth, "Obdurate History: Dinh Q. Lê, the Vietnam War, Photography, and Memory," Art Journal 60, no. 2 (2001), p. 46.

32. Iftikhar Dadi, "Plastic Toys and Urban Craft in South Asia," Prince Claus Journal 10a (2003), p. 150.

33. Stefano Catalini and Dinh Q. Lê, “An Interview with Dinh Q. Lê,” in A Tapestry of Memories: The Art of Dinh Q. Lê (Bellevue, WA: Bellevue Arts Museum, 2007), p. 53.

34. Maria Elena Buszak, "Introduction: The Ordinary Made Extraordinary," in Extra/ordinary: Craft and Contemporary Art, ed. Maria Elena Buszak (Durham, NC: Duke University Press, 2011), p. 5.

35. See Michael Bibby, "Introduction," in The Vietnam War and Postmodernity, ed. Michael Bibby (Amherst, MA: University of Massachusetts Press, 2000), p. ix-xvi. 